\title{
Las olas embravecidas. La antropología propugnada en El engaño de las razas de Fernando Ortiz
}

Gilles Lastra de Matías

Universidad París 8 Vincennes/Saint-Dennis, Francia

\begin{abstract}
El siguiente artículo estudia el pensamiento de Fernando Ortiz a través de su libro El engaño de las razas (1946). El autor cubano asienta las bases de una antropología libre del criterio distintivo y discriminatorio de las razas, libre del uso de la palabra "raza". Esta obra, que supone una concepción plenamente crítica de la historia, resulta inseparable de la reflexión sobre la "transculturación", y en cierta medida, la prolonga.
\end{abstract}

PALABRAS CLAVES: antropología, historia, transculturación, raza, racismo, metáfora.

The following paper approaches Fernando Ortiz's thought through his book El engaño de las razas (1946). The cuban author proposes an anthropology free from the distincti$v e$ and discriminatory criterion of races, free from the use of the word "race". This work, which implies a decidedly critical conception of history, is linked to the reflection on "transculturation", and in a certain extent, a continuation of it.

KEYWORDS: anthropology, history, transculturation, race, racism, metaphor.

Fernando Ortiz (1881-1969) es el autor de una vasta obra de investigación etnográfica e historiográfica dedicada al reconocimiento de los aportes africanos en la cultura cubana. Ligados a una ingente labor de docencia, sus escritos convocan el entero campo de las ciencias humanas, culminando en los estudios musicológicos. Ya miembro del Partido Liberal, se relaciona en los años veinte con el joven Grupo Minorista. Pone coto a su decepcionante experiencia política a raíz de una franca discrepancia con Gerardo Machado, que le obliga a un breve periodo de exilio. Por cierto, Ortiz es un sabio, por encima de todo es un gran defensor del acceso al saber, fundador de revistas y de instituciones, como la Institución Hispanoamericana de Cultura (1926). También fue un innegable precursor, a quien Juan Marinello atribuyó el título a menudo rubricado de "tercer descubridor de Cuba", después de Cristóbal Colón y Alexander von Humboldt: un descubridor cubano de Cuba, un descubridor de lo encubierto. 
En 1946, Ortiz publica El engaño de las razas. ${ }^{1}$ Este libro de divulgación y de compromiso acompañaba la refundición epistemológica emprendida por la antropología. Participaba de la concepción no-racial del hombre: cambiaba la visión del hombre, la lectura de la historia cambiaba. Durante doce capítulos, este autor se empeña en dar cuenta de la refutación científica de la raza como distinción; las declaraciones de la UNESCO sobre el prejuicio científicamente infundado de las razas, son posteriores, en 1950-1951 y con ulteriores adendas.

El engaño de las razas no es una mera producción de saber, sino, de consuno, la producción de un pensamiento, un eslabón del pensamiento orticiano, a tono con la conocida "transculturación". Un pensamiento que es una escritura, con su propio funcionamiento, con su poética. Y una poética de la metáfora. La reflexión de Ortiz se abre a la cultura para abrirse a la historia, a la singularidad de las transformaciones culturales. Deshacerse de la noción de "raza" era entonces, lo es todavía, un verdadero desafío: no se puede abandonar el criterio de la raza sin abandonar conjuntamente las modalidades de pensamiento que lo han nutrido y fundamentado.

\section{En 1946}

Conviene primero hacer hincapié en la fecha de publicación, 1946, después de la culminación inverosímil del antisemitismo. Urge una toma de conciencia. Acabar con los racismos y sus crímenes es una evidencia que se impone, o que debería imponerse a los protagonistas de la Segunda Guerra Mundial. Eso sí, Ortiz apunta igualmente a la urgencia de combatir el racismo en el continente americano:

Nuestro trabajo trata de responder también a las oportunas y nobilísimas excitaciones del gran americano a quien este libro va dedicado. La terminación de la guerra no ha esfumado las humaredas de los racismos y hasta parece haberlas renegrecido en ciertos pueblos de viejos sufridores de tales injusticias sociales. ${ }^{2}$

El engaño de las razas va dedicado a Henry Agard Wallace, el vicepresidente de los Estados Unidos (1940-1944), "gran americano de todas

1 Primera publicación por la editorial Página (La Habana, 1946). Citaremos la segunda edición, con prólogo de Mariano Rodríguez Solveira, El engaño de las razas, Editorial de Ciencias Sociales, La Habana, 1975.

2 Ibídem, "Prólogo del autor", pág. 33. 
las Américas". Que el racismo haya "renegrecido" supone el racismo del color de piel, el color negro en particular, al que se sigue otorgando una indebida trascendencia social y psico-social. Es preciso entender que una liberación está todavía en construcción, doble. Por un lado, el haberse librado del yugo colonial español no ha significado para América Latina una liberación mental: una colonización mental persiste. Por otro lado, en 1946, el colonialismo es una cruenta realidad mundial. Con el nazismo, sin embargo, el opresor europeo acaba de sufrir en carne propia el régimen racial de la opresión, el que justamente caracteriza el colonialismo; su reciente liberación debe redundar en provecho de los colonizados. Es una esperanza que se trasluce a lo largo del libro.

Elaborado con los materiales de un curso de 1944, dictado en La Habana, El engaño de las razas no puede entenderse plenamente sin el contexto cubano. Este año, Ramón Grau San Martín es elegido presidente, sucede al dictatorial Fulgencio Batista, en los bastidores del poder hasta 1952, cuando depone por fuerza a Carlos Prío Socarrás. De más está decir, son tiempos precarios para el progresismo. En 1946, la abolición efectiva de la esclavitud cumple solamente sesenta años; su racismo institucionalizado aún socava la sociedad y moldea las representaciones colectivas. Ortiz brinda un valioso balance en "Por la integración cubana de blancos y negros" (1943), ponencia en la que explicita su trayectoria intelectual y aboga por una cubanidad mulata. La Cuba desintegrada es la Cuba racista. La fase integrativa, de mutuo reconocimiento y respeto, no ha sido alcanzada; se aborda la frágil fase de reivindicación, inficionada por la hostilidad del pasado colonial y agravada por "las políticas extranjeras y predatorias, cuyo corifeo ahora es Hitler con sus racismos brutalitarios". Si "brutalitarios" sobrentiende "totalitarios", el "ahora" es acusador, enlaza el colonialismo occidental con el hitlerismo. La lección de la historia es implacable y se aplica a Cuba: "Quien fomenta el odio enarbolando bandera de raza, se verá un día perseguido a su vez por pretexto de raza también". ${ }^{3}$ El racista se prepara el dogal.

3 Emanación directa de un discurso pronunciado el 12 de diciembre de 1942 (Club Atenas), este texto se publicó en 1943 (Ultra y Revista Bimestre Cubana), luego en Estudios Afrocubanos (19451946). Entre otras publicaciones posteriores, existe la antología a cargo de Salvador Bueno, de la que sacamos las dos citas: "Por la integración cubana de blancos y negros", en Los mejores ensayistas cubanos, Lima, Impr. Torres Aguirre, Biblioteca Básica de Cultura Cubana/Segundo Festival del Libro Cubano, 1959, págs. 37-51. 
En El engaño de las razas, tras una cita de Juan Ginés de Sepúlveda, Ortiz agrega este comentario: "No es de extrañar que tales conceptos se escribieran como supuesta base factual de un tratado que se titulaba Sobre las justas causas de la guerra. ¡Precursor de los nazistas!”. ${ }^{4}$ La exclamación refleja una postura anticolonialista. En el Contrapunteo cubano del tabaco y el azúcar (1940), respecto del mismo Sepúlveda y de Fray Benito de Peñalosa, Ortiz ya preguntaba: “¿Por qué dicen que el delito de genocidio es una manera de criminalidad... moderna?". ${ }^{5}$ Es una postura exenta de afán comparativo, la que adopta asimismo Aimé Césaire en su Discours sur le colonialisme (1955) cuando asemeja el colonialismo a un salvajismo (ensauvagement) que carcomía Europa. Con Hitler, pues, los europeos tenían un espejo del horror de sus colonias, la banalidad del horror colonial: "[...] que una nación que coloniza, que una civilización que justifica la colonización - la fuerza pues - ya es una civilización enferma, una civilización moralmente contagiada, que, irresistiblemente, de consecuencia en consecuencia, de denegación en denegación, anuncia su Hitler, quiero decir su castigo". ${ }^{6}$ El castigo es el contragolpe histórico. La civilización occidental es responsable de Hitler, de parto en la fragua cristiana-colonialistacapitalista.

La noción de "raza" albergó el totalitarismo nazi. Es una noción totalizadora. En el siglo XIX, un seudo-saber de las razas provee la base biológica de las discriminaciones sociales. La racialización legitima la perpetuación de desigualdades sociales y afinca relaciones de dominación. Con las razas, desaparece el individuo: Ortiz lo rescata desde una red tenaz de creencias y de mitificaciones. Rescata a la par el hecho cultural desde la historia natural de los pueblos que halló cabida en una interpretación extraviada del darwinismo, hasta justificar conclusiones eugenistas: un racismo a expensas de lo que suponía al principio un mejor entendimiento del hombre, contra toda tesis poligenista. Tras el evolucionismo biológico, subyace la tentación axiológica, recrudecida por el etnocentrismo; es el "falso evolucionismo" que Claude Lévi-Strauss denunciaba en Race et Histoire (1952): la desigualdad racial reactiva y abona la desigualdad cultural. La

4 Engaño..., cap. VI, pág. 214.

5 Contrapunteo cubano del tabaco y el azúcar. Advertencia de sus contrastes agrarios, económicos, históricos y sociales, su etnografía y su transculturación, Cátedra/Música Mundana Maqueda, Madrid, 2002, pág. 621.

6 Césaire, Aimé: Discours sur le colonialisme, Présence Africaine, Paris, 1995, pág. 16. En adelante, todas las traducciones del francés al español son nuestras. 
historia se resumiría en un progreso uniforme y unilineal, privilegio de los que se erigen en centro y norma. ${ }^{7}$

No hay razas, solamente pretextos para el racismo. Los negros no heredan de una raza, sino de los prejuicios anti-negros. De hecho, esta afirmación de Ortiz: "Lo más negro del negro no está en la negrura de su piel sino en la de su condición social", de suerte que el "negro debe menos negrura a sus morenos antepasados que a sus blancos convivientes". ${ }^{8}$ Llama la atención el que Jean-Paul Sartre, en Réflexions sur la question juive, también publicada en 1946, llegue a una conclusión semejante acerca del Judío: "El Judío es un hombre que los demás consideran como Judío: aquí la verdad sencilla de la cual se debe partir. En este sentido el demócrata tiene razón contra el antisemita: es el antisemita quien hace al Judío". ${ }^{9}$ En todo rigor, la similitud de pensamiento es engañosa, y no por ser diferente la problemática de los dos pensadores. Contra el antisemita, Sartre reflexiona a partir de un Judío abstracto al que rehúsa una existencia concreta: el Judío (el artículo determinado esencializa) es el revés del antisemita y conserva la unidad totalizante de la raza: "No negaré que exista una raza judía". ${ }^{10} \mathrm{Al}$ haber cifrado los Judíos en la figura del Judío-del-antisemita, Sartre habla de "raza", de un conjunto de caracteres somáticos, aunque no le da la trascendencia psico-moral atribuida por el antisemita. El Judío está "en situación", dice Sartre, y su situación es, a la sazón, la de víctima. Según una lectura marcadamente hegeliana de la historia, el Judío no tiene pasado histórico porque, disperso, diaspórico, no tiene territorio nacional: "[...] la colectividad judía es la menos histórica de todas las sociedades ya que no puede guardar memoria sino de un largo martirio, es decir de una larga pasividad". ${ }^{11}$

7 Lévi-Strauss contribuyó a la declaración de la UNESCO de 1950; Race et Histoire prolonga la participación del antropólogo en el trabajo colectivo fomentado por esta misma Organización. Race et Culture (1971) es otra contribución, en aras de un Año internacional contra el racismo.

8 Engaño..., cap. XI, págs. 360-361.

9 Sartre, Jean-Paul: Réflexions sur la question juive, Paul Morihien, Paris, 1946, págs. 88-89.

10 Ibídem, pág. 77. Y más adelante, so capa de prudencia: "habría que decir más bien razas judías" (pág. 78).

11 Ibídem, pág. 85. "Sin historia" ("die keine Geschichte haben”), así es como definía Heidegger en los años 30, con el común y corriente hegelismo, a cierta categoría de hombres, los que no conforman un pueblo, el pueblo-raza: "sin historia", o, en una perspectiva ontologizante, sin capacidad de acceso a su esencia en un advenir histórico-destinal, hombres pues esencialmente irrelevantes. Entre los hombres sin historia, menos que "pueblo" porque sin historia, hay los negros: "Neger wie zum Beispiel Kaffern". A este respecto, se puede consultar: Faye, Emmanuel: Heidegger, l'introduction du nazisme dans la philosophie. Autour des séminaires inédits de 1933-1935, Albin Michel, Paris, 2005, pág.169. 
No se quita historia sin restar humanidad, sin volver inferior y supeditable. El mismo mecanismo ideológico opera en el contexto de la colonización; la negación de la historia conlleva la negación de la cultura, puesto que el colonizador se presenta como un civilizador. De entrada, y con vistas a propugnar una antropología coherente, Ortiz ha rebatido esta argumentación. No recluye a los negros en un martirio, la historia no pertenece al racista: el negro abstracto no existe, salvo en el imaginario blanco. Al aseverar que el antisemita ha inventado al Judío, Sartre llega a validar los prejuicios tradicionales; el Judío no es responsable de sus defectos, de rebote, reales. La época es la misma, los años cuarenta, pero obviamente, frente al filósofo francés, el empirismo del intelectual cubano sustenta un conocimiento crítico.

En Réflexions sur la question juive, Sartre queda anclado en lo que José Martí había llamado con perspicacia las "razas de librería", ${ }^{12}$ fórmula incluida en uno de los epígrafes de El engaño de las razas. Efectivamente, la especulación libresca sustituye la realidad, desliga el saber empírico del saber objetivo. Sin oposición entre pasividad y actividad, el negro no permanece subordinado al blanco-agente-de-la-historia. Además, Ortiz no separa lo social de lo cultural, no establece homología entre dominación social y papel cultural. En eso, el concepto de "transculturación" cobra relevancia; el punto de vista orticiano no es de totalidad, cuentan las relaciones y las interacciones:

La historia americana no puede ser comprendida sin conocer la de todas las esencias étnicas que en este continente se han fundido y sin apreciar cuál ha sido el verdadero resultado de su recíproca transculturación. Decimos recíproca porque hay empeño en hacer creer que no hay tal reciprocidad, y decimos verdadero porque mucho de lo que se tiene por congénito y típicamente racial es sólo supositivo y efecto de sociales reverberaciones. ${ }^{13}$

Ortiz emplea "esencias étnicas" contra los ambiguos caracteres étnicos. Emplea el plural "esencias", sin significación metafísica, para recalcar la participación sustancial de todos los componentes culturales en la historia americana. La reciprocidad trans-cultural tiene la historia como escenario: ni configura un resultado finito, ni descarta la violencia, de defensa y de agresión. Cuando se refiere por segunda y última vez a la transcultura-

12 Es un fragmento de Nuestra América (1891); Mi raza (1893) es muy significativo también. En 1942, Ortiz escribe "Martí y las razas".

13 Engaño..., "Prólogo del autor", pág. 32. 
ción, Ortiz utiliza un verbo recíproco, el de una lucha recíproca, de una resistencia: "[...] cuando se negaban [los indios de América] a adaptarse a la nueva vida que les imponían los conquistadores y misioneros, es decir a transculturarse violentamente $[\ldots]$ ". ${ }^{14}$

\section{El hombre, el individuo, el inmensurable}

La totalización y la dualización son inherentes al racializar. No se puede pensar la raza sin el modo de conocimiento apropiado; mejor dicho, no se puede desprender de la perspectiva racial sin cambiar de modo de conocimiento.

El análisis de la noción de "raza" prolonga y refuerza la reflexión sobre la transculturación iniciada(,) como bien se sabe(,) en el ya mencionado Contrapunteo, escrito antes de la famosa polémica entre Melville J. Herskovits y E. Franklin Frazier. ${ }^{15}$ Los hechos culturales son el hecho de múltiples tránsitos y transformaciones: una apertura hacia el futuro. Culturalmente, cuanto se transmite, sobrevive por adaptaciones, por estrategias y complejos ajustes.

El enfoque cultural posibilita la crítica de la noción de "raza" que en su acepción seudo-científica supone una permanencia hereditaria y una básica no-adaptabilidad (el ambiente). Tal crítica consiste inevitablemente en reconsiderar una historia libre de supuestas leyes, cualesquiera que sean, teológicas o positivistas. El presente no es el reflejo fijo del pasado, menos la prueba de una supuesta fatalidad histórica, a juego con la fatalidad congénita. Una antropología desaprensada de toda metafísica previene la inserción de la historia en una esfera fisiológica: la ideología racial es un aspecto de la incorporación de la historia en la naturaleza, que se trueca en la instancia de un progreso concedido a la historia. En suma, Ortiz airea la relación de antiguo conflictiva entre la antropología y la filosofía de la historia.

Engaño de las razas, engaño del pensamiento:

En estos últimos tiempos se ha recurrido a los más irresponsables artilugios de apariencia científica y a las más absurdas distorsiones de los vocablos y los conceptos

14 Ibídem, cap. VIII, pág. 268.

15 En El engaño de las razas, Ortiz acude a trabajos de Herskovits, pero no el que desató dicha polémica, esto es, The Myth of the Negro Past (1941). 
para proporcionar argumentos de razonabilización a las abusivas políticas. Pero ello es puro engaño. ${ }^{16}$

Aquí, Ortiz recuerda la distorsión ética de la ciencia, un legado decimonónico. La raciología es una ciencia y una política instituidas en función de un determinismo: la historia humana es racialmente determinada y determinable. La transculturación contradice todo tipo de determinismo, inclusive como dialéctica. La común concepción de la aculturación depende del viejo esquema de la asimilación, el de la apropiación sincrética. Ahora bien, no hay aculturación sin des-culturación, sin resolución abierta y siempre singular: una nueva forma cultural con arreglo a condiciones socio-históricas.

Tanto que no sorprende esta aclaración en el Contrapunteo, con un guiño hacia el organicismo funcionalista que en nada era un asenso metodológico:

Al fin, como bien sostiene la escuela de Malinowski, en todo abrazo de culturas sucede lo que en la cópula genética de los individuos: la criatura siempre tiene algo de ambos progenitores, pero también siempre es distinta de cada uno de los dos. En conjunto, el proceso es una transculturación, y este vocablo comprende todas las fases de su parábola. ${ }^{17}$

Una visión no-dualista del hombre supone incluso ir más allá del dualismo naturaleza/cultura. De propósito, Ortiz biologiza la transculturación y transculturaliza la biología: la transculturación es primariamente transmigración de seres humanos, inmigraciones y desarraigos, un amestizamiento biológico-cultural. En El engaño de las razas, el hombre es un intrincamiento de "natura" y "hechura". E, ironía mediante: "Bien claro parece ya el hecho real de que es la sociedad humana y no la naturaleza quien crea las razas [...] la raza es de hechura [...]. Toda raza es hechiza"; por ende: "Todo racismo es hechizo. Hechizo por artificio, por superstición y por ceguera y arrebato de sus creyentes. Hechizo, que tanto es a veces como fetiche". Lo que resulta verdaderamente congénito con las razas es, en fin, la "congénita peligrosidad social"18 de la palabra "raza". En el Contrapunteo, Ortiz ya había sugerido el invento engañoso; cotejaba ciertos tabacólogos con los raciólogos del momento: "[...] so pretexto de defender las condiciones del

16 Engaño..., pág. 30. Ortiz se apoya en autoridades intelectuales tales como Ashley Montagu, Franz Boas, Ruth Benedict, Theodosius Dobzhansky, Friedrich Hertz, Magnus Hirschfeld, Julian Huxley.

17 Contrapunteo..., pág. 260.

18 Engaño..., cap. XII, págs. 379 y 399. 
tabaco según los egoísmos y banderas de sus países, han creado razas, ligas, nombres y marcas de vitola tan fantásticas y artificiales como las mitológicas razas inventadas por los racismos del día". ${ }^{19}$

Partiendo de la definición seudo-científica de la raza, Ortiz muestra su flagrante inconsistencia. La demuestra empíricamente cuando constata una pluralidad y una variabilidad tan irrefragables como inabarcables. Un empirismo que no prescinde de las diferencias físicas y fisiológicas, pero un empirismo absuelto de cualquier tentativa arbitraria (estadística) de reducir las variaciones a una permanencia, las variedades a una identidad, de subsumir lo individual bajo lo general, los caracteres somáticos bajo tipos psicológicos. Ortiz da algunos ejemplos de la fiebre taxonómica que se había apoderado de la antropología: un exceso que se invalida por sí mismo. El hombre no es clasificable, es inmensurable, pese al absurdo de una antropología hecha antropo-metría. El hombre se recononoce en el individuo, humanamente irreductible a una raza. Y el individuo es ante todo el proceso de individuación. Conque el hombre, en Contrapunteo, era comparable a la mata de café, el polo opuesto de la caña de azúcar: "En el tabaco la uniformidad nunca se tuvo ni se tendrá", 20 "El tabaco es bueno o malo, pero busca siempre individualidad", "Todos los azúcares serán iguales; todos los tabacos son diversos". ${ }^{21}$

El empirismo objetivo anula el argumento de lógico:

Es absurdo tratar de aplicar a los seres humanos el principio de identidad. Ello es imposible hasta las lucubraciones matemáticas, de donde parece que ha sido ahuyentado lo absoluto. En la naturaleza no hay dos cosas iguales, ni en el espacio ni en el tiempo. El teorema de que dos cosas iguales a una tercera son iguales entre sí no pasa de ser una filigrana metafísica.

Una lógica de la equivalencia y del silogismo:

Se pensó que si dos cosas iguales a una tercera son iguales entre sí, por la introducción del término constitución se hallaría la equivalencia entre las razas y las almas. Pero ese encadenamiento silogístico es improcedente; le falta verdad en sus premisas. ${ }^{22}$

19 Contrapunteo..., pág. 162.

20 Ibídem, pág. 159. Más adelante: "Y haciéndose la reproducción de las plantas de tabaco por medio de semillas, numerosísimas en toda mata, no es raro que en cada cosecha surjan variedades, hijas de los infinitos cruzamientos y mestizajes, de las selecciones que hacen los codiciosos cuidados del cosechero y de las misteriosas mutaciones y los caprichos cromosómicos de la naturaleza. Y cada hoja de tabaco es distinta de las otras, según los besos que le diera el sol".

21 Ibídem, págs. 163-164.

22 Engaño..., cap. III, pág. 115; y cap. VII, pág. 248. También, cap. VIII, pág. 261. 
La equivalencia, apodíctica, escamotea el hecho empírico: es una aplicación raciológica de la diferencia exterior observable, una deducción psico-socio-moral de supuestos rasgos definitorios. Frente a esa homología raciológica, silogística y deductiva, Ortiz contrapone su visión empírica de la homología entre naturaleza y cultura, contrapone su visión del hombreindividuo. En un plano genético:

Ya desde su instante originario todo humano fenómeno de herencia es binario y dilémico. Dos progenitores son los que se juntan en la obra, dos individuos, necesariamente dos y, por ser dos, también necesariamente diversos. Y todos los factores genitivos que se combinarán para la creación del nuevo ser han de irse sacando de cada uno de ellos y en cada caso por dilema, ora lo uno ora lo otro, pero no de ambos en común y por igual. ${ }^{23}$

Este proceso se compagina con el de a-des-neo-culturación. Acaece una co-producción, más que una re-producción. La binariedad sitúa el origen en la diversidad, que se redistribuye de manera aleatoria en el individuo. Por otra parte: "Binariedad en sus fuentes, en su caudal, en su confluencia y en el conjunto de sus resultados vitales. Por lo tanto, toda herencia humana implica esencialmente un mestizaje", y, "Todo ser humano es único por su propia individualidad y es a la vez mestizo por razón de la esencial binariedad hereditaria de su congenitura". ${ }^{24}$ Importa notar que el mestizaje es un hecho universal, que el individuo es un cumplimiento de lo universal, ubicado en lo particular y no a la inversa. ${ }^{25}$ Se trata de una crítica del universalismo etnocéntrico, o sea, de la extensión de lo particular a lo universal.

Por lo cual, el pensamiento de Ortiz es difícilmente encasillable en el programa funcional-estructuralista. Estructuras hay, y las circunstancias históricas, el contexto social amoldan su singularidad. Contra la esencialización: una historización. Ortiz no se deja seducir por leyes de isomorfismo, ni por cualquier ideal de convergencia. El contrapunteo es una noción dramática: muestra la coexistencia de contrastes constitutivos en una organización social, el plurifacetismo de sus elementos funcionales.

Las distinciones raciales desempeñan una función social y política de discriminación. De ahí, inferir que una sociedad sin razas es una sociedad

23 Ibídem, cap. IV, pág. 141.

24 Ibídem, respectivamente págs. 148 y 149.

25 Análogamente, en Contrapunteo: "Y aun para la historia universal de los fenómenos económicos y sus reflejos sociales, pocas lecciones habrá más fecundas que las del azúcar y del tabaco en Cuba" (pág. 138). 
sin clases sería incurrir en una sobreinterpretación marxista, como Sartre con el antisemitismo: "[...] el antisemitismo es una representación mítica y burguesa de la lucha de clases y que no podría existir en una sociedad sin clase". ${ }^{26}$ Ortiz desiste de toda racionalización histórica para combatir las ideologías racistas y sus implicaciones socio-económicas. Aunque respetable, la alegación universalista y utopista, como es la "raza humana" defendida entre otros por Karl Kautsky o la "raza cósmica" de José Vasconcelos, no escapan del peligro totalizador de la raza. Para Ortiz, no hay raza, ni pasada, ni proyectada en el futuro:

Unos buscan la pureza de la raza hacia atrás, remontando la historia; otros procuran en el porvenir, por la creciente mezcolanza de las diferencias. Unos creen que las hererogeneidades fueron más en la prehistoria y que la humanidad va por sus cruces a la pureza sintética; otros piensan que la raza pura, y acaso singular, fue primero $\left[\ldots .{ }^{27}\right.$

No hay ninguna pureza, aun a escala humana. El hombre no es una nostalgia, ni un aplazamiento; la diversidad no es una etapa, es el hombre. La humanidad se aloja en el individuo y en la contingencia de la vida. La desteologización es radical.

\section{Una palabra, una tempestad}

Una filología precisa debe neutralizar lo que Ortiz llama la "congénita peligrosidad social" de la palabra "raza". La ironía es implícita; para desarmar el engaño, la palabra "raza" tiene que ser de algún modo racializada: sus rasgos ideológicos han adquirido permanencia, que las circuntancias no llegan a modificar.

En El engaño de las razas, el origen etimológico concuerda con el uso y su fuerza prescriptiva. La palabra "raza" concuerda con el uso racista. En efecto, el racismo tiene una profunda raíz económica que Ortiz señala desde la etimología, incierta, de "raza". Retiene la opción semítica que le permite subrayar la animalización o bestialización aneja a la definición exclusivamente biológica del hombre: es una voz en primer lugar aplicada al ganado, y luego a los esclavos. En "raza" resuena toda la historia de la trata negrera en América, toda la nomenclatura zoológica de los mestizajes: entre muchos más, el mulato, el lobo, el jíbaro, el coyote, el cambujo, el

26 Sartre: Réflexions..., págs. 193-194.

27 Engaño..., cap. X, pág. 331. 
pardo. Una voz que, siendo semítica, se enraizó tempranamente en la Península Ibérica, para hacerse española. Y la aritmética sanguínea del tercerón, cuarterón, quinterón, etc., tiene un inevitable paralelo con la "limpieza de sangre" inquisitorial. La palabra "raza" está muy íntimamente unida a la explotación económica del hombre, a la deshumanización. No por casualidad la esclavitud trajo las especulaciones sobre la monogénesis o poligénesis del hombre, con la jerarquía afín. Un debate filosófico-religioso en el que se destaca la figura teológica del "Hijo de Cham": la piel negra como culpa de un hijo que conculca la autoridad paterna. ${ }^{28}$ Una división de los pueblos, en predilectos y malditos, que Ortiz prefiere rebatir nuevamente con ironía: no "hay estadísticas fehacientes de si en el infierno predominan por obra de sus perversidades los hombres o las mujeres, los dolicocéfalos o los braquicéfalos, y las rubias o las trigueñas. El diablo sabe mucho y no permite que tales cosas se aclaren $[\ldots]{ }^{\prime 2} .{ }^{29}$

Desde el segundo párrafo de El engaño de las razas, Ortiz advierte: "El mismo vocablo raza no tiene una pura generación y llega a nosotros manchado de infamia. Raza es voz de mala cuna y de mala vida". ${ }^{30}$ Impura, infame y mal nacida, la palabra "raza" carga con las taras habitualmente imputadas por la raciología: esta palabra es lo que designa, lo que mal designa. Por lo demás, la "mala vida" es una expresión muy orticiana que caracteriza más bien una primera fase de reflexión sobre el mestizaje cultural, anterior a la transculturación. No es descabellado pensar en una alusión, como si Ortiz quisiera dejar constancia de una fase ulterior de pensamiento, que enmienda el alcance psico-social de sus primeros trabajos en los que habían arraigado las teorías criminológicas y sus atavismos. ${ }^{31}$

28 Ortiz menciona esta legitimación de la esclavitud por la maldición de Noé hacia la descendencia de Cham (ibídem, pág. 29). La exégesis agustiniana proporciona el principal marco explicativo (De Civitate Dei, XVI, 1-3). Noé prueba el vino de su viña, regresa ebrio a su tienda y se desnuda. Cham mira la desnudez de Noé, lo cuenta a sus dos hermanos Sem y Jafet que cubren al padre con un manto. Cham significa "calor", y su descendencia fue relacionada con la mitológica Etiopía. Fácil era deducir una predisposición fisiológica de la culpabilidad, expuesta por ejemplo en el De instauranda Aethiopum salute (1627) de Alonso de Sandoval.

29 Engaño..., cap. XI, pág. 361.

30 Ibídem, cap. I, pág. 35.

31 El primer volumen de Hampa afro-cubana (Los negros brujos, 1906) contiene un prólogo del criminalista Cesare Lombroso. Una obra que Roger Bastide definía de manera algo perentoria como el estudio "de la cultura africana como la de un Lumpenproletariado, viviendo en los márgenes de la sociedad" (Les Amériques noires. Les civilisations africaines dans le Nouveau Monde, Payot, Paris, 1967, pág. 7). Lo cierto es que Ortiz, abogado de formación, se interesaba por los fenómenos socio-criminológicos y publicó un manual al respecto (Identificación dactiloscópica, Impr. "La Universal”, La Habana, 1913). En tanto que miembro de la Cámara de Representantes, ideó un Proyecto de Código Criminal Cubano (1926). 
Bastaría con releer los textos de Entre cubanos (1913), libro que ratifica alguno que otro prejuicio: ahí, aparece la "voz de mala cuna y de mala vida", acompañada de un indisoluble positivismo que procura "definir sociológicamente lo que somos, lo que hemos sido y ayudar a dirigirnos con fundamentos positivos hacia lo que debemos ser". ${ }^{32}$ Cuba no sería Cuba sin las huellas africanas, es una convicción temprana de Ortiz. Empero, los negros constituyen máximamente un factor demográfico y demopsicológico; un "alma negra" vive un proceso de atenuación en el "alma blanca". En la balbuciente República, su discurso reformista se acoge a un patriotismo tributario del cientismo finisecular.

Sea lo que fuere, Ortiz se sirve en gran parte de la etimología que Unamuno había propuesto reiteradamente: la ganadería, la zoología. Se conoce el vínculo de Ortiz con el filósofo español (Entre cubanos le es dedicado). Carlos Serrano habló de un "caso de regeneracionismo transatlántico", ${ }^{33}$ Ricardo Viñalet de "regeneracionismo transculturado".${ }^{34} \mathrm{El}$ año 1898, huelga decirlo, no tenía el mismo significado para los dos. Coincidieron en la necesidad, premiosa, de un sobresalto intelectual. Para Ortiz, significaba una deshispanización: la colonia mental. Para Unamuno, el discurso colonial perduraba, renovado en el de la Hispanidad.

En El engaño de las razas, Ortiz cita a Unamuno a fin de burlar la promulgación del "Día de la Raza" (inventado por ley en 1922), pero no da la fuente bibliográfica del fragmento citado, dedicado a la explicación etimológica. El detalle tiene importancia; es un fragmento sacado de un corto artículo titulado "Svástica" (1932). A la sazón, Unamuno se siente preocupado por la nueva simbología nazi de la cruz (la "cruz disimulada"), ya en voga en América y sobre todo en el País Vasco. Lo que le preocupa es que esta cruz se haya convertido en un "emblema racista" y que represente un "monstruoso internacionalismo nacionalista, un racismo de las diferentes razas. Una locura". ${ }^{35}$

32 Conclusión de "Las supervivencias africanas en Cuba", Entre cubanos. Psicología tropical, Editorial de Ciencias Sociales, La Habana, 1993, págs. 86-89. Ortiz sigue usando la palabra "raza" en Contrapunteo, en un sentido desprovisto de prejuicios por descontado, conforme al uso convencional (color, pueblo, origen); para la relación “componentes raciales”/”fusión nacional”: Contrapunteo, pág. 201.

33 Serrano, Carlos: "Miguel de Unamuno y Fernando Ortiz. Un caso de regeneracionismo transatlántico", Nueva Revista de Filología Española, t. XXXV, 1, Madrid, 1987, págs. 299-310. Muy aleccionador, este trabajo parte de la correspondencia.

34 Viñalet, Ricardo: Fernando Ortiz ante las secuelas del 98. Un regeneracionismo transculturado, Editorial de Ciencias Sociales, La Habana, 2001.

35 Unamuno, Miguel de: “[Svástica]”, Obras completas, Afrodisio Aguado, Madrid, 1958, vol. XI, págs. 1088-1091. 
Cabría añadir que Unamuno condena más el racismo que la raza. Había puesto las razas en el espíritu: "raza espiritual" y no "raza hispánica". Su exactitud filológica corre parejo con la defensa de la Hispanidad: la lengua como "sangre espiritual". Es la filología del siglo XIX. Unamuno pone la patria chica en la patria grande, la nación en la lengua, América en la lengua española. Su universalidad es católica: la pretensión católica a la universalidad, la inclusión de lo particular en lo universal. Es el esquema humanístico del saber, el esquema místico del sujeto, el de la asimilación y de la expansión periférica. Así que la europeización unamuniana es al mismo tiempo un eurocentrismo. Vale recordar que, antes de calificar la libertad cubana de "desastre", en una amplia nota de En torno al casticismo (1895), Unamuno tomaba por su cuenta las tesis frenológicas y les asignaba un extravagante sentido geográfico, de las circunvoluciones del cerebro a las circunvoluciones de las costas mediterráneas: "Es incalculable el efecto sobre nuestra cultura de haber activado la vida periférica de las costas el descubrimiento de América", y finalmente: "el tener el europeo más periférico el cerebro que el negro de África es reflejo de tener Europa más perímetro de costa, seis veces más respecto al área, que el África. ¡Maravilloso cerebro el Mediterráneo, viejo cerebro de Europa [...]!". ${ }^{36}$ Se trasmina el consabido tema de la "africanización", cuyo vector principal hubiera sido el semitismo.

En torno al casticismo hace al caso. El primer párrafo del prólogo de El engaño de las razas contiene una alegoría que parece evocar y desactivar la alegoría empleada por Unamuno para su "intrahistoria": la tradición eterna, eternamente presente en la lengua, es el fondo calmado y silencioso del mar; el rumor espumoso de las olas simboliza los acontecimientos de la historia. El anti-positivismo de Unamuno radica en los dualismos de las profundidades y de la superficie, de lo permanente y de lo temporal. Una visión de la cultura cómplice de la raciología, que Ortiz contrarresta con un terminante "todo dura y todo muda" ${ }^{37}$ Tal es la contra-alegoría proemial de las olas embravecidas:

La humanidad está debatiéndose en un torbellino de intereses económicos, nacionales y sociales, cubierto casi siempre por espumaje de razas. Éstas no son sino las burbujas que coronan las olas embravecidas; las fuerzas que las forman y agitan están debajo y generalmente no se ven. Por eso son temas inevitables de cada día así las

36 Unamuno, Miguel de: En torno al casticismo, Espasa-Calpe, Madrid, 1943, págs. 120-121.

37 Engaño..., cap. IV, pág. 138. 
razas, todas ellas impuras y arbitrarias, como los racismos, siempre agresivos y todos

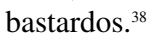

Ortiz se apega indefectiblemente a la historia: la palabra "raza" es la cresta de un problema mucho más profundo, una palabra en la cima de una tempestad humana de prejuicios y de supersticiones, de intereses de poder. Las profundidades pueden explicar la superficie: es menester una tarea de análisis, una tarea de disolución.

\section{El buen uso de la metáfora}

Teniendo en cuenta la etimología privilegiada por Ortiz, la palabra "raza" es una metáfora, muchas palabras lo son. Es una metáfora zoológica: en el transporte metafórico, una sustitución de la realidad, un transporte fuera de la humanidad a imagen de la trata de los esclavos.

La trascendencia, la homología psico-social de la raciología son el mismo movimiento metafórico. Contra éste, contra todo campo explicativo insatisfactorio, el de prejuicios y supersticiones, Ortiz metaforiza y contrametaforiza, no desideologiza los imaginarios, su indignación no tiene prescripción. No es pedagogía sin más; en El engaño de las razas, la poética de la metáfora es una ética de la metáfora. Ya no se debe transportar la vida hacia las razas. Sí, remite a una metáfora de la guerra y del amor, una sinergía vital que consiste en una lucha. Un resto de darwinismo despunta, siempre que se entienda como un anti-creacionismo.

Por consiguiente: "Los genes para procrear necesitan casamiento. Diríase que la vida no existe en los genes célibes, inertes como materia; y que es el amor lo que los acerca y combina en esas familias de genes que son los cromosomas". ${ }^{39}$ Con metáfora musical, del mulato musical: "Diríase que en cuanto a esto los genes son como las teclas de un piano, invariablemente blancas y negras, las cuales combinándose producen los sonidos de las más varias sinfonías". ${ }^{40}$ La binariedad vital que preside al nacimiento humano (¿y cómo no recordar la binariedad contrapuntística que preside al nacimiento de Cuba?) es metáfora del amor y del deseo: "Los genes no pueden responder de su permanencia y constancia. La infi-

38 Ibídem, pág. 29.

39 Ibídem, cap. IV, pág. 146.

40 Ibídem, cap. IV, pág. 158. 
delidad, queja frecuente de los grandes amores que viven los seres humanos, parece que ya se manifiesta en los ínfimos amores ultramicroscópicos". Metáfora de la conquista amorosa: "En el rito amoroso de la pareja humana y en su íntimo momento sacramental de la creación hay siempre terceros; alcahuetes sonsacadores, rivales y embarazosos, y coros no siempre oportunos para el epitalamio". ${ }^{41}$ Metáfora de la danza: "El engendro es la obra de una cuadrilla, de dos parejas; en la figura creadora dos danzantes se cruzan y enlazan, otros dos los acompañan sin dar paso en el cuadro y esperan el lance venidero". De la "cuadrilla" del danzante, a la cuadrilla del obrero: no todos los genes colaboran, "una parte de ellos hallará empleo; la otra quedará en huelga forzada". ${ }^{42} Y$ metáfora de la escritura, de la interacción entre naturaleza y ambiente: "La herencia será la pluma escritora, pero el ambiente será la página donde escribir y sólo la relación vital de la una con la otra dará la escritura, su contenido y su estilo". ${ }_{43}$

La transmisión de la vida es transmisión de una potencialidad; la baraja genética no se somete a predestinación alguna:

No se crea, como la superstición popular, que el hombre viene al mundo con un número limitado de posibles descargas para los amorosos combates de la reproducción a lo largo de la vida, como va el soldado a la batalla con un número contado de cartuchos en la canana. El soldado del amor, como Cupido, podrá disparar ilimitadamente sus propias flechas $[\ldots] .^{44}$

Por lo tanto, "los caracteres y las cualidades no se transmiten sino metafóricamente". Una manera de lance de dados mallarmeano que nunca puede agotar el azar, la vida es un infinito encuentro, la contingencia de la herencia: "[...] los genes son sus dados y en el lance del engendro caerán aquéllos por tal o cual de sus caras [...]" ${ }^{45}$ La individuación de un genotipo en fenotipo niega la fatalidad hereditaria afecta al discurso racializante y su consecuente metaforización de la exterioridad física.

La insubordinable diversidad que se manifiesta sobre los semblantes, Ortiz la define como la resolución pacífica de la lucha por la vida: "Toda herencia es mixtigénica. La herencia es un tratado de paz y alianza tras la pugna entre dos ejércitos de genes que fueron movidos al delirante encuen-

\footnotetext{
41 Ibídem, cap. V, págs. 174 y 184.

42 Ibídem, cap. IV, pág. 155.

43 Ibídem, cap. IX, pág. 300.

44 Ibídem, cap. IV, pág. 147.

45 Ibídem, págs. 163 y 165.
} 
tro por su impetuoso anhelo de perpetuación". ${ }^{46}$ Dicho de otro modo: "Cada pareja de hombre y mujer en trance de amor es una negación potencial de la raza" ${ }^{47}$ Todas las metáforas invocadas en El engaño de las razas son una sola metáfora abierta: una esperanza, un devenir, una inmanencia en la historia, donde todo se transforma y deviene. A todas luces, la idea de paz atempera la visión nietzscheana de la "voluntad de potencia" atinente a las fuerzas activas de un instinto de vida demasiado espontáneo y agresivo.

Es la lucha intelectual, a favor de la historia, en detrimento de la mitificación: "La sociedad humana, que creó las razas, habrá de suprimirlas [...] esos fantasmas enemigos que son las razas; doblemente inhumanos, tanto por irreales como por crueles". ${ }^{48}$ El engaño de las razas termina así, con la imperativa "desracificación" de la humanidad y la correspondiente des-metaforización. Cuando Ortiz propone, contra la "mala palabra", los neologismos "androtipo" y "ecoandrotipo", propone una literalización, una nueva palabra y una nueva lógica de pensamiento. Recupera la dimensión científica denegada a la palabra "raza", sin avalorar el universalismo exacerbado que sume las diferencias en una comunidad humana, de origen o de destinación, tan irreal como un mundo racializado.

La esperanza de Ortiz es una esperanza al precio de muchas desilusiones: habrá que afrontar nuevas olas embravecidas. El engaño de las razas se puede leer como una argumentación propiciatoria, a semejanza de los ritos estudiados en un libro concomitante acerca del huracán. ${ }^{49}$ Sobre el drama transcultural de la conquista española, había escrito: "Luego, un huracán de cultura; es Europa". ${ }^{50}$ En el drama atmosférico de una reciente tempestad histórica, la Segunda Guerra Mundial, Ortiz escribe al ritmo de una conjuración, ritmo al que responde el manejo de la metáfora: catácresis y relegación, la metáfora propone y pone a distancia.

Para concluir, que prevalezca una concepción de la historia. El hombre avanza a oscuras, su mañana es incierta, la tiene que construir consciente de ciertos engaños. La historia no tiene telos. El papel de la ciencia es eminente: permite repatriar la humanidad en la singularidad y liberar la antropología del colonialismo. Permite desalojar al ser humano de las razas

46 Ibídem, pág. 149.

47 Ibídem, cap. X, pág. 318.

48 Ibídem, cap. XII, pág. 402.

49 El huracán. Su mitología y sus símbolos, FCE, México, 1947. Una obra que Ortiz anticipa en trabajos de 1944-1945.

50 Contrapunteo..., pág. 256. 
para devolverle su condición histórica y cultural. Ahora bien, para un pensador que ha acometido contra los etnocentrismos, se plantea una cuestión indudablemente complementaria: es el hombre quien debe salir del centro donde pretende estar. En El engaño de las razas, en último lugar, Ortiz cuestiona el antropocentrismo: el término "ecoandrotipo" tiene esta fuerte resonancia. El elogio del torbellino de la vida es el elogio de la diversidad humana, en lo viviente.

Recibido el 7 de marzo de 2008 Aceptado el 4 de noviembre de 2008 